\title{
Nevbet-i Müretteb'in farklı coğrafyalardaki izleri üzerine bir inceleme
}

\author{
Ali İhsan Alemli* \\ Nilgün Doğrusöz** \\ *Sorumlu Yazar, Öğr. Gör., Kastamonu Üniversitesi Eğitim Fakültesi Temel Eğitim Bölümü, \\ https: / / orcid.org/0000-0003-0974-0876, e-Mail:aalemli@kastamonu.edu.tr \\ **Prof. Dr., İstanbul Teknik Üniversitesi Türk Musikisi Devlet Konservatuarı, Müzik Teorisi \\ Bölümü, https://orcid.org/0000-0003-4818-4075, e-Mail:dogrusozn@itu.edu.tr
}

DOI 10.12975/rastmd.2021927 Submitted October 22, 2021 Accepted December 5, 2021

\section{Özet}

Tarih öncesinden itibaren Türk müzik kültüründe çeșitli değișmeler meydana gelmiștir. Müzik kültürü bu süreçte, sürekli dönüșerek günümüzdeki șeklini almıștır. 10. Yüzyılda Farabî, Pisagor'un yüzlerce yı önce ortaya koyduğu gezegenlerin sesleriyle ilgili düșüncelerini kabul etmeyip sesin meydana gelişini cisimlerin birbirlerine vurulmasıyla açıklayarak Horasan Tamburu üzerinde 17'li ses sistemini geliștirmiștir. Daha sonraları bu ses sistemi, Urmevî’nin de katkılarıyla uzun yıllar etkisini göstererek Abdülkadir Merâgi, Yusuf Kırșehrî, Hızır bin Abdullah, Ahmedoğlu Şükrullah gibi teorisyenlerin edvarlarında karșımıza çıkmıștır. Farklı yüzyıllar ve coğrafyalarda bu sistemi kullanan çeșitli tür ve formlar meydana gelmiștir. Bunlardan biri makam müziğinde yüzyıllar boyunca müzik çevrelerini etkileyen nevbet-i mürettebdir. Nevbet-i mürettebin uzun bir dönem müzik çevrelerince büyük ilgi görmesine karșın yaklașık 16. yüzyıl itibarıyla adından söz edilmeyiși bu araștırmanın yapılması gereğini doğurmuștur. Bu araștırma sonucunda nevbet-i mürettebin metinlerarası ilișkiler kurularak kültürlerarası etkileșimler neticesinde bir dönüșüme uğradığı tespit edilmiștir. Bu dönüșüm, geniş bir coğrafyaya yayılarak farklı kültürlerde farklı isimlerle karşımıza çıkmaktadır. Nevbet-i müretteb; Mağrip ülkelerinde nuba, Türkiye'de fasıl, Suriye ve Mısır'da waslah, İran'da destgâh, Azerbaycan'da mugam, Irak'da makam, Özbekistan ve Tacikistan'da makam (șașmakom), Malezya'da nobat, Doğu Türkistan'da muqam olarak kendini gösterir. Nevbet-i mürettebin çıkış noktası için, bahsi geçen türlerin en eskisi olarak yazılı kaynaklarda 8. ve 9. yüzyıllarda karșılaștığımız nubayı ișaret etmek mümkündür.

\section{Anahtar Kelimeler}

kültürlerarasılık, metinlerarasılık, nevbet-i müretteb, nuba

\section{Giriș}

15. yüzyılın önemli müzik türlerinden biri olan nevbet-i mürettebden özellikle Abdülkadir Merâgi, eserlerinde sıkça bahsetmiștir. Câmi'ul Elhân adlı eserinde Merâgi'nin nevbet-i müretteb hakkında geniș bilgiler vermesine karșın bu türün günümüze ulașmıș bir ezgi örneği bulunmamaktadır. Rağbet gördüğü dönemde müzik kültüründe derin izler bırakan nevbet-i müretteb hakkında, daha sonraları akıbetinin ne olduğu; bir değișime uğrayıp uğramadığı üzerine detaylı bir inceleme yapılmamıștır. Günümüzde bu konuda yapılmış az sayıda çalıșma mevcuttur. Bu çalıșmalar arasında, 2007 yılında Süreyya Agayeva'nın İslâm Ansiklopedisi'ndeki nevbet-i müretteb maddesi ve 2017 yılında 
Recep Uslu'nun Türk Dünyası Sosyal Araștırmalar Dergisi'nde yayınlanan makalesi "Nevbet-i müretteb: XIXV. Yüzyılların Gözde Musiki Biçimi Nasıldı?" sayılabilir. Ayrıca bazı ulusal ve uluslararası yayınlarda nevbet- $i$ mürettebin kısmen bahsinin geçtiği söylenebilir. Çalıșmada kullanılan bu kaynaklara ek olarak; Angelika Jung'un "Quellen der traditionellen kunstmusik der Usbeken und Tadshiken Mittelasiens" [Orta Asya Özbek ve Taciklerinin geleneksel sanat müziğinin kaynakları] adlı kitabı; Ann Lucas'ın, "Music of a thousand years a new history of Persian musical traditions" adlı kitabı; Louis Ibsen al-Faruqi'nin "The suite in Islamic history and culture" adlı makalesi sayılabilir. Yapılan bu araștırmaya temel teșkil edecek soru șudur: Nevbet-i mürettebin tarihsel süreç içinde ortaya çıkıșı, serüveni ve değișimiyle birlikte farklı kültürlerdeki yansımaları ne șekilde meydana gelmiștir?

$\mathrm{Bu}$ araștırmada temel olarak nitel araștırma yöntemi kullanılmıștır. Nitel araștırma, sosyal dünyanın nasıl yorumlandığı, anlașıldığı, tecrübe edildiğ $i$ ve üretildiği ile ilgili olarak genel anlamda yorumlayıcı bir ideolojidir (Mason, 1996: 4). Tarama modelinde betimsel bir araștırma olan bu çalıșmada, nevbet-i mürettebin farklı kültürlerde nasıl bir dönüșüme uğradığının kültürlerarasılık ve metinlerarasılık kavramları açısından değerlendirmeleri yapılmıștır. $\mathrm{Bu}$ değerlendirmelerde nevbet- $i$ müretteb olgusuna tarih, müzikoloji, edebiyat ve sosyoloji alanları çerçevesinde disiplinlerarası yaklașılmıștır.

Tarih boyunca kültürler, çeșitli sebeplerle birbirlerini etkilemișlerdir. Kültürrlerarasılık terimiyle ifade edilen bu etkileșimler sonucu ilk zamanlar bölgesel olan bazı unsurlar farklı coğrafyalarda ortaya çlkabilir. Bu unsurlar, bazen tamamen aynı bazen de küçük değișiklerle kendini gösterir. Cunio (2008), Kimberlin ve Euba'nın çalıșmasından alıntı yaparak kültürlerarası müziği, bestecisinin farklı kültürlerden olduğu durumda birden çok kültürün özelliklerini barındıran müzik șeklinde tanımlar (s. 21).

Kültürlerarası müziğin gerçekleșmesi, tarihsel ve etnomüzikolojik bir bakıș açısı ile geleneksel metinler ve ezgiler çerçevesinde yeniden olușturma sürecini tanımlamanın bir yoludur. Bu gerçekleșme, belirli bir dönemin müziğini yeniden inșa etmenin mümkün olmadığı ve bunun yerine yeniden yapılanma sürecinin kullanıldığı öncülüyle bașlar (Cunio, 2008: 21). Kültürlerarası iletișimde müziğin önemli bir yeri vardır. Ortak müzik kültürlerinde farklı toplumların müziklerinin birbirleri arasında bütünlük gösteren benzerlikleri düșünüldüğüunde, müziğin kültürlerarası iletișimdeki katkısı daha da belirginleșir. Kültürlerarası iletişimde müziğin önemini belirtmek için söz konusu toplumların iletișiminin tarihsel sürecine bakmak ve günümüze getiren kültürel dokuyu analiz etmek gerekir (Uslu ve Kurtuldu, 2018: 236). Kültürel hoșgörü geliștiğinde kültürlerarası müziğin de geliștiği söylenebilir.

\section{Nevbet-i Müretteb'in Kısa Tarihi}

Tertip edilmiş (müretteb) bir sıra (nevbet) gözetilerek dört ya da beș bölümden olușmuş, bölümlerin içinde ve diğer bölüm aralarında güfte, usûl, makam birlikteliği bulunan müzik biçimleri nevbet-i müretteb olarak adlandırılmaktadır (Parmaksız, 2016: 180). Tek makamdaki birleșik form yapısı ve dört ya da beș bölümden olușması 
ile nevbet-i müretteb, genel hatlarıyla konuyla ilgilenen müzikologlar tarafından bir çeșit süite ya da fasıla benzetilmiștir. Wright'a göre nevbet, terim olarak Ebu'l Ferec'in "Kitab al Aghani" adl nağmeler kitabında "dönüș” anlamında kullanılmıștır (Wright, 1993: 1042).

Bu türün izine "Binbir Gece Masalları"2 adlı halk hikâyelerinin anlatıldığı kitapta rastlanır ve burada ud ile icra edilmiş, ritmik bir yapıyı temsil eden darij adlı nevbet hareketinden söz edilir (Farmer, 1945: 47). Darij, Mağrip ülkelerinde hâlen icra edilmekte olan nuba türünün bir bölümünü teșkil eder.

Nevbet-i mürettebin içerdiği bölümlere, yazılı kaynaklarda ilk olarak Keykâvus bin İskender'in 1087 yılında yazdığı "Kābusnâme" adlı eserinde rastlanmaktadır. Keykâvus, oğlu Gilân Şâh'a öğütlerini dile getirdiği kitabının çalgıcıların töresini anlattığı 36 . bölümünde "bir mecliste eğer çalgıcılık yaparsan hep aynı tarz icrada bulunma bazen hafif, bazen ağır çal" der. Bunları söylerken bestekârların padișahlar için hafif âhenkte ${ }^{3}$ hüsrevâni, yașlılar için râh-ı girân adını verdikleri daha ağır âhenkte besteler yaptıklarını belirtir. Gençler için basit denilen hafif vezinli,

1 10. yüzyılda kaleme alınmıș șiir ve nağmeler içeren 20 ciltlik kitap.

2 Farmer, bu eserde Bağdat Balıkçısı Halife, Ibrahim ibn el-Mehdi ve Tüccarın Kızkardeși, Ebu'l-Shamat ve Ni'mat ibn al-Rabi'a, Nu'm ve köle kızı masallarında nevbet icrasının varlığından söz eder. Binbir Gece Masalları, yüzyıllar boyu yapılan eklemelerle gelișerek anonimleșmiș ve son hâli Memlükler döneminde Misır'da șekillenmiștir. Ünlü seyyah Antoine Galland bu eseri 18. yüzyılda Fransızca'ya çevirerek Avrupa insanı ile tanıștırmıștır.

3 Âhenk terimi, "uygunluk, düzen” anlamı tașıdığı gibi “cümbüș etme, çalıp söyleme" anlamlarına da gelmektedir. Buradaki ifade daha çok "șarkı söyleme" manasındadır. Bkz. Ferit Devellioğlu, Osmanlıca-Türkçe. Ansiklopedik Lügat, 1986 Ankara. kıvrak besteler yapıldığını ifade ederken çocuk ve genç kadınlar için de küçük terâne ve nağmeler bestelendiğini söyler (Keykâvus bin İskender, t.y.: 79-80). Böylelikle Kābusnâme'de ismi zikredilmeden nevbet-i mürettebin bölümleri ifade edilirken bunun bir tertib içinde gerçekleștiğinin altı çizilir. Keykâvus, eserinde bahsi geçen farklı türlerin bir araya getirilișini dinleyici kitlesinin çeșitliliğine bağlar (Jung, 1989: 139). Bu çeșitlilik içerisinde yaș, cinsiyet ve makam-mevkiden bahsetmek mümkündür. Kābusnâme'de yaşl, genç, çocuk ve genç kadınlar için yapılarına (mizaçlarına) uygun eserlerin bestelendiği ifade edilirken; padișahlar için bestelenen daha hafif tarzdaki eserlerin, onları eğlendirmek adına yapıldığı görülmektedir. Kābusnâme'de izine rastlanan hüsrevâni, Yusuf Kırșehrî'nin edvârında ${ }^{4}$ nevbet-i müretteb bahsinde șöyle geçer:

"Bilgil kim nevbet-i müretteb oldur kim evvel ki bünyâd eyleye bir makam göstere andan sonra bir pișrev ide andan sonra hüsrevâni ide hüsrevâni oldur kim yine bir makam göstere andan sonra bir pișrev ide yine ide eger sakil eger hafif iki devr nakıss nakarat göstere andan sonra bir kavl ide andan sonra bir gazel ide andan sonra bir pâre ide evvel terâne ola andan sonra bir kavl dahı andan fürûdașt ide çün bu ka'ideyi ri'ayet eyleye nevbet tamâm olmış olur" (Doğrusöz, 2012: 146)

Yusuf Kırșehrî edvârındaki ifadelerden yola çıkarak hüsrevâni'nin bir nakış nakarattan ibaret olduğu söylenebilir.

4 Geniș bilgi için bkz. Nilgün Doğrusöz, Yusuf Kırșehrî'nin Müzik Teorisi, Kırșehir Valiliği, 2012 Kırșehir. 
Nakıșın hareketli ve hafif bir yapıyı temsil etmesi ise Kābusnâme'deki hüsrevâninin padișahlar için bestelenmiș hafif tarzdaki eser tâbirini destekler. Kābusnâme'de nevbet düzeni basitten karmaşığa doğru destân-i hüsrevâni, râh, hafif, terâne șeklinde sıralanır. Destân-i hüsrevâni geleneksel bir destan șarkısını ifade eder. Râh ise yol, yöntem anlamına gelir ki ağır tempolu usûl üzerine kurulmuș çalgısal parçaları temsil eder. Farsça râh teriminin Farâbi tarafından enstrümantal bir prélude için zaten kullanılmıs olan Arapça tarîka'ya tekabül etmesi ilgi çekicidir (Jung, 1989: 139). Râh'ın sözcük anlamı için yol gösterme, makamı tanıtma gibi görevler üstlendiğini söylemek mümkündür. Râh, bu çerçevede günümüzdeki peșrev ya da taksim anlamına gelen çalgısal bir bölüm olarak tanımlanabilir.

Keykâvus'tan sonra 13. yüzyılda Tifâși "Mut'atü'l-esmâ fî ilmi's-semâ"5 adlı eserinde, nevbet-i müretteb bölümlerini kavl, gazel, terâne, zamâne ve diğer kavl olarak belirtir (Tancî'den aktaran Uslu, 2017: 180). Aynı yüzyılda Kudbeddin Şirâzi'nin "Dürretü’t-tâc" adlı eserinin musiki risâlesinde Urmevî'ye ait bir kavl ${ }^{6}$ örneği bulunurken Memlük hükümdarı el Nâsır'ın çocuklarına müzik dersleri veren Kutayla adındaki müzisyenin, Urmevî'nin 130 civarındaki nevbet bestesinin çoğunu ezberlediği bilinmektedir (Neubauer, 1995: 806).

\section{4. yüzyılda Seyyid Şerîf Cürcânî "Şerh-i} Kitâbü'l-Edvâr" adlı eserinde nevbet-i müretteb hakkında bilgiler verir. Nevbet-i mürettebin detaylı anlatımı

5 Tifâși bu eserinde müzik ve halk danslarını inceler. 613. Yüzyılın büyük âlimlerinden Kudbeddin Şirâzi'nin ebced müzik yazısıyla kaleme aldığı nevbet-i müretteb bölümlerinden biri olan bu parçada, forte (kuvvetli), piano (hafif) gibi dinamikleri göstermesi ilgi çekicidir.
15. yüzyılda Abdülkadir Merâgi'nin "Câmi'ul Elhân", "Fevâid-i Așere" ve "Makâsıdü'l Elhân" adlı eserlerinde görülür. Makâsıdü’l Elhân'da kendisine ait nevbet-i müretteb örneklerinin bulunduğunu söylediği “Kenzü’l Elhân” adlı eseri ise henüz bulunamamıștır.

Merâgi'ye göre kudemâ ${ }^{7}$ dönemlerden beri bilinen nevbet-i mürettebden, Herat müzik ekolü temsilcilerinden Benâi yazdığı Risâle-i Mûsiki adlı eserinde söz etmiș ve Merâgi'ye atıfta bulunmuștur (Abbasoğlu, 2015: 234). Ayrıca Anadolu edvar geleneği temsilcilerinden Hızır bin Abdullah, Seydî ve Yusuf Kırșehrî de eserlerinde nevbet-i mürettebden söz etmișlerdir. Yusuf Kırșehrî, Safiyyüddin Urmevî'nin üç yüz civarında nevbet-i müretteb bestelediğini ve o çağda yüz elli tanesinin bilindiğini ifade eder (Doğrusöz, 2012: 146).

Hızır bin Abdullah, "Kitâbül Edvâr" adlı eserinde nevbet-i müretteb bahsinde șunları ifade eder:

"Bilgil ki bu ilm-i mûsikide bunca acîb ve garîb hikayetlerden bir gereklü dahı budur kim bilmek gerek kim nevbet-i müretteb nice olıcak tamâm olur şöyle gerekdür kim eger sâzende ise sazını düzmek gerek bir eksuksuz tamam andan sonra bașlaya bir makâm göstere dahi ol makamda bir pîșrev çala ve eyde ve sonra tasnif eyide andan bir daire çala yahud bir nağme eyde sonra nevaht çala tamam eyde dura bu nevbet urûm vilayetinde olan sazendeleründür amma Arabun nevbet-i mürettebi oldur kim bir makamda bir usulde gerek hafîf olsun gerek sakîl gerek verșan gerekse

7 Kadim kelimesinin çoğulu olarak "eskiler" yani eskiden yașamıș olan büyükler anlamındadır. 
muhammes olsun her kankı darbda olursa olsun bir makamda bir usulde amma asl- ו hafîf ve sakildür dört tasnif eyde evveline kavl dirler ikincisine gazel dirler üçüncüsüne terane dirler dördüncüsüne fürûdașt dirler eger sazende ise sonra bir nevaht ider heman Arab'un üstadları nevbeti budur amma nevbet-i müretteb de bir kaç nev’iledür...” (Çelik, 2001: 244).

Hızır bin Abdullah, nevbet-i mürettebi bölümleriyle tanıttığı Kitâbül Edvâr'da Anadolu ve Arap müzisyenlerinin nevbetlerini anlatırken sâzendelerin nevaht çalması gerektiğini ifade eder. Nevaht, kelime olarak saz çalma anlamına gelir ki bunun da taksimi ișaret ettiği söylenebilir.

Abdülkadir Merâgi, Câmi'ul Elhân'da 9 adet formdan bahsederek bunları şöyle sıralar: nevbet-i müretteb, basit, darbeyn, küllü'd-durûb, küllü'n-nagam, Arap neșîdi, amel, pîșrev ve zahme. Ayrıca nevbet-i mürettebin dört bölümlü olduğunu ve genellikle sakîl-i evvel, sakîl-i sânî, sakîl-i remel, fahte ve Türkî-i asl usûlleriyle bestelendiğini ifade ederken isterlerse bestecilerin farklı usûlleri de kullanabileceğini dile getirir. Eserde nevbet-i müretteb bölümleri kavl, gazel, terâne, fürûdașt șeklinde belirtilirken, Merâgi müstezâd ${ }^{8}$ adını verdiği beșinci bölümü kendisinin eklediğini ifade eder (Sezikli, 2007: 248).

Merâgi'nin ölümünden sonra Hüseyin Baykara döneminde Herat'ta yașayan Alișah bin Hacıbüke, Ali Şir Nevâi'ye sunduğu “Mukaddimetü’l-Usûl” adlı eserinde müzik biçimlerini anlatırken sazların vezinsiz olarak nevaht çalması 8 Merâgi'nin nevbet-i mürettebe eklenen beșinci bölüm için bu ismi vermesinin sebebi müstezad kelimesinin Arapça'da artmış, çoğalmıș anlamını taşımasıdır. gerektiğini ifade eder. Nevaht, daha önce de belirtildiği üzere taksim olarak düșünülebilir. Alișah, kitabında vezinli ezgilerin çeșitlerini tarif ederken nevbet-i mürettebin de bahsinin geçtiği şu açıklamalarda bulunur:

“Peșrev, musikinin güftesiz șeklidir. Diğer adı tarîkadır. Eğer hafif usullerden ise-hezec ve evfer gibi-bunların haneleri üçten az olmamalıdır. Tekrar eden kısma serbend-i peșrev derler. Ama eğer eser bir șiir kıtası olursa, dört hâneden az olmamalıdır. Her hânede bir beyitin tekrar edip etmediğine bakmalıyız. Eğer tekrar yoksa ona nakış derler. Ancak bunun hafif usullerden olması şartı vardır. Eğer dönüş yapılmıș ise ona savt derler. Onun da üç kısmı vardır. Birinci kısım tekrarlıdır. İkinci kısmın meyan hânesinde tekrar vardır. Birincisine tasnif derler ve çoğu zaman hafif veya sakîl usulü ile olur. Eğer okunan șiir Arapça ise ona kavl derler. Ama Arapça olmasa gazel derler. Eğer hem Arapça hem de bașka bir dil ile bir arada ise ona kavl-i murassa' denir. İkincisi, eğer meyan hânenin tamamının tekrarını içine alırsa ona amel denir. Eğer dört tasnif ve bir amel toplanırsa-ki bu doğru bir birleșme olmaz-bunların usul bakımından nim sakîl ve hafifü'ssakîl olması gerekir. Eğer ikinci kıta kavl, ikincisi gazel üçüncüsü tasnif ise, bu üçlüye terâne derler. Bunların șiirleri genellikle rubai türündedir. Dördüncü kavle fürûdașt derler ki, bu geçmişte zikredilen üç șeyin sanatlarını kendinde toplamıștır. Beșinci kıtayı rahmetli Abdülkadir keşfetmiş ve ona müstezad demiștir. Isște bu topluluğa nevbet-i müretteb denmiștir. Padișahların dıșındakileri 
medh ${ }^{9}$ için kullanılır. Nakıș ve savt bu formda kullanılmaz. On yedi meșhur formun bir arada kullanilmasina küllü’n-negam, meșhur usullerin bir araya getirilmesine de küll-i durub derler. Küllü'n-negam ve küll-i durub bir arada kullanılır ise, Hoca Abdülkadir ona külliyat adını vermiștir” (Çakır, 1999: 107-108).

Alișah, nevbet-i mürettebin meydana gelișini sıraladığı bölümlerin birleșimi olarak yorumlar. 16. yüzyıl bașında vefat eden Alișah'tan sonra da nevbet-i müretteb bazı eserlerde kendini gösterir. Bunlardan biri olan Seydî'nin "el-Matla" adlı eserinde, "Der beyân-1 âdâb-ı mûsiki" bașlığı altında bu türden șu șekilde söz edilir:

"Ve iy Dilșâd bu ilmin evvel âdâbından biri budur kim bir kiși nevbet-i müretteb itmeye șur'u itse, evvel başlıya bir makâm göstere, andan sonra pîșrev ide, andan sonra hüsrevâni göstere. Tenbih: hüsrevâni oldur kim bir makâm göstere, ol makamda pîșrevinden sonra ya sakîl ya hafîf iki devir nekârat-ı nakșiyle göstere, andan sonra bir kavl dahî ide, badehü bir gazel ide ve bir pâre dahî ide kim ana nizâne dirler, sonra bir kavl dahi ide kim ana fürûdașt dirler ve eger bu tertib üzre gûyendelik itse edeb-i musikiyi saklayıb nevbet-i müretteb tamâm itmiș ola..." (Arısoy, 1988: 83).

El-Matla'da Seydî, nevbet-i mürettebin tanımını yaparken Hızır bin Abdullah'ın sâzendelerle ilgili ifadelerine karșılık gûyendelere (hânende) yani șarkıyı

9 Nevbet-i mürettebi padișahların dıșındakileri övmek için bestelendiğinin ifade edilmesi dikkat çekicidir. okuyanlara vurgu yapmaktadır. Görüldüğüü üzere bahsi geçen edvarlarda, özellikle hüsrevâni hakkındaki açıklamalar çerçevesinde Yusuf Kırșehrî, Hızır bin Abdullah ve Seydî'nin nevbet-i müretteb üzerine benzer ifadeleri bulunmaktadır. Yine aynı yüzyılda Necmeddin Kevkebîî, 1522 yılında kaleme aldığı "Risâle-i Musiki" adlı eserinde nevbet-i mürettebin isminden bahsetmeden bölümlerini kavl, gazel, terâne ve fürûdașt olarak sıralar ve bu formların birleșmesiyle nevbe türünün oluștuğunu ifade eder (Çakır, 2010: 170). Yusuf Kırșehrî, Hızır bin Abdullah ve Seydî'nin nevbet-i müretteb hakkındaki açıklamalarında bulunan benzerlikleri, farklı dönemlerdeki edvar kitapları arasındaki metinlerarasılık ile ifade etmek mümkündür. Metinlerarasılık, yazılı kaynaklar arasındaki etkileșimler olarak değerlendirilirken ileride de belirtileceği üzere müziksel metinlerarasılık kavramı müziklerarasılık olarak tanımlanabilir.

Owen Wright (1992), çeșitli kütüphanelerdeki müellifleri bilinmeyen güfte mecmualarıla birlikte Hafız Post'un da güfte mecmuasını ele aldığı "Words without songs" adl eserinde nevbet-i mürettebi organize edilmiş bir döngü ve dört ya da beș hareketten olușmuș bir süit olarak tanımlar (s. 313). Wright, nevbe olarak ifade edilen bu tür için nevbet-i müretteb teriminin kullanılmasının daha doğru olduğunu belirtir. Aynı eserde, nevbet-i müretteb için Merâgi'nin bahsettiği 9 adet formdan birincisi olduğu bildirilirken

10 16. yüzyılda yașamıș olan Kevkebî, Herat'ta din, astronomi ve müzik alanında eğitim almıș, Özbek kültüründe dönemin önemli isimlerinden biridir. Geniș bilgi için bkz. Ahmet Çakır, Necmeddîn Kevkebî’nin Müzik Teorisi, Etüt Yayınları 2010, Samsun. 
(s. 208); güfte mecmualarının zamansal ilișkilerinin incelendiği bölümde bu türün 16. yüzyıl ortalarına kadar varlığını sürdürdüğü ifade edilir (Wright, 1992: 11).

\section{Türk Askerî Muiziği ve Nevbet}

Nevbet-i müretteb ile etimolojik yakınlığından ve bazı icra benzerliklerinden dolayı Türk askerî müziğindeki nevbetden de söz edilmesi gerekir. 11. yüzyılda Kașgarlı Mahmud'un "Dîvânü Lugāt-it-Türk" adlı eserinde Türkmenlerden bahsedilen maddede “Balasağun'daki sarayın önünde beyler için her gün üç yüz altmış nevbet davulu vuruluyordu" ifadesi geçer (Asker ve Asker, 2008: 34). Uygur Müziği'nde de on iki makam, yapısal olarak nevbet kökenli türlerle bağlantılıdır. Doğu Türkistan coğrafyasında önemli bir yere sahip olan on iki makam, sadece müzik alanında değil aynı zamanda edebî yapitlarda da kendine yer bulmuștur. Uygur Makamı'nı konu alan edebî eserlerin farklı dönemlerdeki Uygur edebiyatına ait șiirler içermesi, on iki makamın 14. yüzyıldan itibaren bir ilerleme içerisinde olduğunu yansıtmaktadır (İnayet, 2007: 382).

14. yüzyıl divan şairlerinden Seyyid Nesîmî, "Tek âlemde senin yüzün şahlığa beș nevbet çaldı, ind-i sultanlık tahtını mekânsız evce kaldır" diyerek sevdiğine yazdığı șiirinde gece gündüz, belirli vakitlerde saray ya da meșhur ziyaretgâhlarda çalınan nevbetden bahseder. (Agayeva, 1979: 5). 16. yüzyıl divan șairlerinden Bâkî, așkı sultanlara benzeterek her gün beș vakit çalınan nevbete șu beyitle vurgu yapar: "Husrevâne penc nevbet çaldı heft iklimde, nüh kıbâbın yankulandurdı sipihrün mîr-i așk"11 (Şahin, 2011: 37-38). Selçuklularda sultanların kapılarında beș nevbet (nevbet-i pençgâne) ve meliklerin kapılarında üç nevbet çalınırdı. Osmanlı devrinde mehterhâne adını alan, hâkimiyet ve gücü temsil eden bu askerî müzik sultanların heybetini gösteriyordu. Saraylarda nevbet müziği takım ve heyetine nevbethâne, çalanlara da nevbetiyân adı veriliyordu (Turan, 2008: 392). Hunlar ve Göktürklerden itibaren hâkimiyet sembolü kabul edilen nevbet geleneği, İslâm dönemindeki Türk devletlerinde de devam ederek Osmanlılara kadar sürdürülmüștür. Türk ve İslâm devletlerinde nevbet, savaș harici bir güç sembolü olarak öne çıkmış, nevbet sayısı ve zamanları bazı kurallar içinde uygulanmıș, kurallara uymayanlar otoriteye asilik yaptığı gerekçesiyle cezalandırılmıștır (Özaydın, 2007: 39).

Evliya Çelebi Seyahatnâme'sinde özellikle kaleleri anlattığı bölümlerde belirli zamanlarda icra edilen nevbetlerden söz eder. Evliya Çelebi 300 hâneli, 26 kuleli Zile kalesinden bahsettiği bölümde 100 askerin her gece 2 kez nevbet çaldığını (Kahraman ve Dağlı, 1999: 138); Selânik kalesinin anlatıldığı bölümde de her gece kalenin 5 farklı yerinde nevbet mehterhânesi çalındığını dile getirir (Kahraman, Dağı ve Dankoff, 2003: 62).

Farmer (1945), "The minstrelsy of the Arabian nights" adlı eserinde nauba terimiyle bahsettiği türün iki șekilde icra edildiğini ifade eder. Birincisi

11 Așk emîri yedi iklimde padișahlara yarașır biçimde beș vakit nevbet çaldırıp gökyüzünün dokuz kubbesini yankılandırdı. Bu beyitte așk, insanı ele geçirip yönetmesi anlamında padișaha benzetilir ve Selçuklu döneminde her gün beș defa namaz vakitleri çaldırılan nevbete gönderme yapılır (Şahin, 2011: 38). 
barıș yıllarında dıș mekânda ve belirli saatlerde, ses yoğunluğu yüksek çalgılarla icra edilen sözsüz askerî müzik; diğeri ise geceleri oda müziği tarzında icra edilen nevbettir (Farmer, 1945: 5-7). Bir oda müziği olarak icra edilen nevbet-i müretteb, ișlevsel farklılıklarıyla ve icra tarzı ile askerî müzik olan nevbetten ayrılır.

\section{Nuba Geleneği}

Tarih boyunca Türkler, İranlılar ve Araplar şiire verdikleri değer nedeniyle sözlü müziği ön planda tutmușlardır. Türk sözlü müzik formlarından kaside, gazel, şarkı, beste, murabba, kâr ve semâi; Arap sözlü müzik formlarından da kaside, gazel, muvașşah ve zecel sayılabilir. Nuba ise değișim, dönüş anlamlarıyla Mağrip'in en eski ve en büyük döngüsel formudur (And, 2003: 704). Alman müzikolog Curt Sachs (1943), nubayı aynı tonalitede [makamda] dokuz bölümden meydana gelmiș bir kantat olarak tanımlar (Sachs, 1943: 391).

Abbasiler dönemi 9. yüzyıl Bağdat'ında nuba besteleri yaptığı bilinen Ziryâb lakaplı Ali bin Nâfi, Abbâsi halifesi Harun Reșid'in huzurunda geliștirmiș olduğu kendine ait udu çalınca halife tarafından taltif edilir. Bu durumu kıskanan hocası İshak el-Mevsılî ondan șehri terk etmesini ister $^{12}$ (Erkoçoğlu ve Arslan, 2013: 464). Bu hikâyenin doğruluğu kesin olmamakla beraber herhangi bir sebeple Bağdat'tan ayrılan Ziryâb, çalıșmalarını önce Tunus Kayrevan'da daha sonra da İspanya Kurtuba'da sürdürmüștür. Ziryâb'ın Akdeniz coğrafyasına olan bu göçü ile nuba müziğinin Mağrip ve Endülüs'e

12 Owen Wright, bu hikâyenin inandırıcılıktan uzak olduğunu ve el-Makkâri tarafından kurgulandığını öne sürmektedir. Bkz. Owen Wright, "Music In Muslim Spain", The Legacy Of Muslim Spain, Ed. Salma Khadra Jayyusi, E. J. Brill, 1992, s. 556. tașındığı, bununla beraber İshak elMevsılî'nin de nuba geleneğini Bağdat'ta devam ettirdiği düşünülebilir.

Ilk taslakları 10. yüzyılda Irak'ta yazılmaya bașlanan Binbir Gece Masalları adlı eserde bahsi geçen darijin, Ziryâb tarafından bulunmușolması muhtemeldir. 15. yüzyılda Hızır bin Abdullah'ın Kitâbü'l-Edvâr adlı eserinde Arapların nevbeti ifadesini kullanarak bölümlerini belirttiği nevbet-i mürettebin nuba ile bağlantılı olduğu düșünülebilir.

Nuba, batı müziğindeki süit gibi hareketler arasında karmașık bir bağlantı sistemine sahip çok yönlü bir türdür. Nuba, sadece bir modun değil aynı zamanda eserin olușturulduğu kurallar dizisidir. Ziryâb'ın tabai'a adı verilen günün her saati için bir tane olmak üzere 24 nuba bestelediği araștırmacılar tarafından dile getirilmektedir (Marks, t.y.). Bu sistemi anlatan nadir belgelerden biri, Granadalı ibn al-Kâtib al-Salmâni'nin bir șiiridir. Șiir, 24 Endülüs nubasının dört ana dala bölünmesini anlatır. Farmer, bu șiiri "An old Moorish tutor" adlı makalesinde yayınlamıștır (Shiloah, 1995: 84).

Nuba, Batı ve Doğu Arap Dünyası olarak iki farklı coğrafî alanda kendini gösterir. Bir Endülüs müziği olan nuba, Davis (2004)'e göre 10 ila 17. yüzyıllarda Müslüman ve Yahudiler tarafından diğer coğrafî bölgelere tașınır. 16. yüzyıldan 19. yüzyılın sonlarına kadar Türkler bașta olmak üzere Misır ve Avrupa'da çeșitli yabancı etkilere maruz kalan nuba, temelde popüler olmakla beraber aristokrat bir himâyeye sahip olmuștur. Modern devlet himâyesine kadar nubanın bașlıca savunucuları sûfiler idi. Tasavvuf mekânlarının dıșında, nuba profesyonel müzisyenler tarafından kahvehanelerde, 
düğün ve sünnet gibi dinî ve aile kutlamalarında da icra edilirdi (Davis, 2004: 2, 4).

\section{Nevbet-i Müretteb ve Suiit İlișkisi}

Süit ile yapısal benzerliklerinden dolayı bazı müzikologların İslâmî Süit olarak değerlendirdiği nevbet-i müretteb, sonraki dönemlerde kültürlerarası etkileșimlerin de katkısıyla farklı coğrafyalarda farklı isimlerle ortaya çıkmıștır.

Süit, aynı tonalite ve formdaki dans parçalarının art arda sıralanmasıyla olușmuș bir müzik türüdür. İlk örneklerinin Ortaçağ’da görüldüğü, farklı bölümlerin birleșmesiyle olușan sözsüz müzik türlerinin en eskisidir. Bazı Fransız besteciler, besteledikleri süitleri ordre diye tanımlarlar ki bu terim sıra, düzen anlamlarını içerir (Hodeir, 1990/1992: 114). Ordre, nevbet-i müretteb teriminin (nevbet: sıra, müretteb: düzenlenmiș, tertip edilmiș) anlamıyla da örtüșmektedir. Agayeva (2007) ise nevbet-i müretteb için süit ifadesinin uygun olmadığını bunun yerine döngüsel anlamına gelen cycle teriminin daha doğru olduğunu belirtmektedir (Agayeva, 2007: 42). Süitin aynı tonalitede bestelenmiș allemande, courante, sarabande ve gigue adlı bölümlerinin nevbet-i mürettebdeki aynı makamla bestelenmiș kavl, gazel, terâne ve fürûdașt ile yakınlık gösterdiği söylenebilir. Yine bazı süitlerin bașında icra edilen prélude, fasıl müziğindeki peșrev ile ișlevsel benzerlikler göstermektedir.

Lois Ibsen al Faruqi, "The suite in Islamic history and culture" adlı makalesinde nevbeti İslâm müzik kültüründeki süit olarak tanımlar. Faruqi, ayrıca 14. yüzyılın ünlü gezgini İbn Battûta'nın gittiği birçok ülkede askerî grupların gerçekleștirdiği süit benzeri performanslardan söz ettiğini dile getirir. Aynı çalıșmada Ali Jihad Racy'nin bu türe compound form (birleșik form) denilmesini önerdiği de ifade edilir (al Faruqi, 1985: 46, 48, 63).

\section{Misır ve Suriye'deki Dönguisel \\ Muizik: Waslah}

Bazı müzikologların İslâmi süit, kantat ya da fantasia gibi ifadelerle tanımladığı nevbet ve benzer türler için Ali Jihad Racy birleșik form terimini kullanır. Waslah da Misır ve Suriye'de kendini gösteren birleșik yapılı bir müzik türüdür. Waslah'ın ortaya çıkıș tarihi, belge eksikliği sebebiyle net olarak bilinmemektedir. Bununla birlikte waslah, 19. yüzyıl sonlarında ud, ney ve tef çalgılarına batı kemanının da eklenmesiyle erkek vokalle birlikte seslendirilen uzun soluklu takımsal bir icra olarak kendini gösterir (Racy, 1983: 397).

\section{İran Klasik Muiziğinde Destgâh}

İran klasik müziğindeki destgâh da tașıdığı düzen anlamıyla nevbet-i müretteb gibi takımsal yapıda icra edilen bir müzik türüdür. Müretteb kelimesinin tertip edilmiș, destgâh kelimesinin ise düzen anlamlarına gelmesi ilgi çekicidir. Destgâh, geleneksel bir șekilde gruplandırılmıș bir dizi parçayı tanımlar. Bu parçaların birincisi destgâhın makamsal kimliğini ifade eder. Bu makam, eserin icrası boyunca kadanslı melodik kalıplar çerçevesinde sık sık belirtildiği için baskın bir yapıdadır (Farhat, 2004: 19).

İran klasik müziğindeki doğaçlama ezgilere genel bir ifadeyle redif denmektedir. Redif terimi, 12 adet destgâhı meydana getiren eserler takımını ifade etmek için de kullanılır (Çak, 2018: 53). Bu destgâhların temel 
kabul edilen yedisi șûr, segâh, çargâh, hümâyun, mâhur, rast pençgâh, nevâ'dır. Diğer beși ise, temel destgâhlara bağlı olan abuata, dastî, bayât-i Türk, afșâri ve bayat-i isfahandır. Destgâhlarda gûşe denilen bazı ezgiler bulunur ki bunlar diğer destgâhlara geçkileri sağlayan bir köprü vazifesi görür. Her destgâhın özel bir ismi vardır ve daramad adı verilen giriș müziğiyle bașlar (Ardalan, 2012: 6). Pîș daramad da denilen bu giriș parçası, fasıl müziğindeki peșrev ile anlam ve ișlev bakımından benzerlik gösterir.

İranlı siyasetçi ve müzikolog Mehdikulu Hidayet, Mejma al- Adwar adlı kitabında, İran sanat müziğindeki destgâhın Merâgi'nin eserlerindeki nevbet-i mürettebin taklit edilmesinden meydana geldiğini belirtirken bu benzerliği destgâhların da nevbet-i mürettebde olduğu gibi tertiplenmiș (müretteb) kompozisyon formlarından oluşmasıyla ilișkilendirir. Hidâyet, fürûdașt teriminin forud ve dasht kelimelerinin birleșmesinden meydana geldiğini belirtir (Lucas, 2019: 148). Forud, Farsça'da iniș, sona ermek anlamına gelir ve doğaçlama yoluyla çeșitlemeye bağlı, sabit kalıplı melodik bir kadansı teșkil eder (Farhat, 2004: 25). Fürûdașt, daha önce de bahsedildiği üzere 4 bölümlü nevbet-i mürettebde (Merâgi'nin beșinci bölüm olarak eklediği müstezaddan önce) eserin final bölümünü olușturmaktadır.

\section{Özbek ve Tacik Kültürlerinde}

\section{Şașmakom}

Farsça șeş ile Arapça makam kelimelerinden meydana gelen şașmakom, Özbekçe'de, altı fasıl anlamına gelir. Şașmakom ile ilgili belgelere 18. yüzyılın ortalarından itibaren rastlanmaktadır. Genel olarak Orta Asya'da 19. yüzyılın başlarından itibaren makam terimi asıl anlamından farklı sekilde ritmik ve melodik bir mod içerisinde sırayla düzenlenmiș süit [fasıl] anlamına da gelmektedir (Sumits ve Levin, 2012: 235). Özbek ve Taciklerdeki altı adet fasıl șunlardır: Büzürk, rast, nevâ, dügâh, segâh ve ırak fasilları. Her biri geleneksel İran müziğinin destgâhlarından olușan șașmakom (Abubakr, 2017: 68) yapisal olarak nevbet-i müretteb ile benzerlik gösterir.

Abdülkâdir Merâgî, “Şerh-i Kitâbü’lEdvâr" adlı eserinin Topkapı Sarayı Kütüphanesi 3470 numaralı nüshasında maddeler halinde otobiyografisini verir. Merâgi bu otobiyografide Türk, Tacik ve Arapların ortamında nevbet ve gazel okuduğunu söyler.

“Kadir Allah'a șükür olsun. O ki her diyarda beni aziz kıldı. Yıllarca huzur ve ișret içinde, dünya sultanları ile huzurlu oldum. Zamanın șahlarının meclislerinde, köșkte, bağda, sarayda ve eyvanda can yakan sazlar çaldım. Çok sayıda güzel besteler yaptım. Ầâbı, padișahlardan öğrendim. Aradığımı onlarda buldum. Önce cihan șahı sultan Üveys, asırların sahibi sultan Üveys. Âdil bir padișah, dünyaya adâleti o verdi ve dağıttı. Bazen mecliste șarkı söylememi isterdi. Oku ki hüzünden kurtulayım derdi. Bazen de eğlence meclisinde, Türk, Tacik ve Arapların huzurunda. Ey Abdülkâdir ud çal!" derdi. Sen ki dünyada benzerin yoktur. Kâh nevbet yap, kâh gazel oku. Sen ki âlemde benzerin yok" (Kolukırık, 2009: 15-16).

Merâgi eserlerini icra ederken aynı meclisteki Taciklerin nevbetten etkilenip ilham aldığı ve bu müzik türünü kendi memleketlerine götürdüğü düșünülebilir. Ayrıca Timurlu devletinin 
çöküș döneminde Herat'ın Özbeklere geçişiyle Özbek ve Tacik kültüründeki șașmakom türünün de ilk nüvelerinin oluştuğu söylenebilir. Buhara ${ }^{13}$ doğumlu Necmeddin Kevkebî, Herat'ta müzik eğitimini Merâgi'nin öğrencilerinden biri olduğu ileri sürülen Hoca Yusuf Burhan'dan almıștır (Çakır, 2010: 12). Kevkebî'nin Merâgi ekolünden gelmiș olmasının, nevbet-i müretteb ile șaşmakom arasındaki benzerlik sebeplerinden biri olduğu söylenebilir.

\section{Uzakdoğu'da Nevbet İzleri}

Takımsal tarzda icra edilen nevbet kökenli türlerden biri olan nobat ise Malezya'da icra edilmektedir. Nobat, İslâm dininin 13 . yüzyılda bölgeye gelişinden itibaren Sumatra, Malezya yarım adası ile Brunei'nin Malay saraylarında icra edilen davul ve üflemeli çalgılar topluluğu olarak kendini gösterir. Geleneksel Malay topluluklarında nobat, siyâsi sınırların görsel ve işitsel olarak çizilmesi anlamına gelmektedir (Raja Iskandar bin Raja Halid ${ }^{14}$, 2015: 76).

Seljuq (1976), "Some notes on the origin and development of naubat" adlı makalesinde, nevbetin Malezya'ya ilk gelișini ele alır. Bir Müslüman krallığı olan Pasai'nin sultanı Sâlih, göreve bașlama töreninde nevbet çaldırmıștır. Müslüman Malezya krallığının en eski eseri olan Hikayat Raja Raja Pasai'ye göre çalınan bu nevbet, Halil ibrahim nevbeti olarak bilinir (Seljuq, 1976: 146). Aynı makalede, nevbetin bölümleri kavl, gazel, terâne, müstezâd ve fürûdașt șeklinde belirtilir. Ayrıca Fatih Sultan Mehmet'in İstanbul'u

13 Özbekistan sınırları içinde Mâverâünnehir bölgesinde bulunan tarihî șehir.

14 The Malay Nobat: A History of Encounters, Accommodation and Development adl tezini bizimle paylaștığı için Raja Iskandar bin Raja Halid'e teșekkür ederiz. fethettiğinde Ayasofya'ya girerken, İranlı șair Sadi Şirâzi'ye ait șu mısraları söylediği belirtilir: Baykuș, Efrâsiyâb ${ }^{15}$ 'ın kubbesinde nevbet dövüyor, örümcek Kisrâ ${ }^{16}$ kemerinde perde örüyor (Seljuq, 1976: 142). Fatih Sultan Mehmet'in okuduğu bu misralar Tursun Bey'in İstanbul'un fethini anlattığı "Târîh-i ebü'l-feth" adlı eserinde yer almıștır. Bu beyit, bazı kaynaklarda küçük farklarla karșımıza çıkar ancak hepsinde de baykușun mecâzî bir șekilde nevbet çaldığı ifade edilir. Böylece nevbetin o dönem hem Acem memleketinde, hem de Anadolu'da revaçta olduğu söylenebilir.

\section{Eski Fasıl (Fasl- Atik) ve Nevbet Illișkisi}

Fasıl müziği de yapısal olarak bahsi geçen türlerle benzerlik gösterir. Fasıl, Arapça bölüm, devre anlamlarına gelen fasl kelimesinden gelir. Fasıl kavramı aynı makamda fakat farkl formlarda sözlü ve çalgısal eserlerin belirli bir sıra halinde art arda gelmesinden olușan bir tür konser süiti șeklinde tarif edilir (Behar, 2015: 38). Geleneksel fasıl müziği sırasıyla peșrev, kâr, murabbâ, ağır semâi, yürük semâi ve saz semâisi'nden meydana gelen bir icra șeklidir (Eken Küçükaksoy, 2009: 3). Klasik fasıl olarak da ifade edilebilecek bu yapının, sonraki dönemlerde sadece ağır tempodan giderek hızlanan bir konser programı hâline dönüștüğü görülmektedir.

Birbiri ardına sıralı olan güfteli eserlerle ve bu eserlerin aralarında veya sonlarında bulunan çeșitli çalgı müziklerinden oluşan nevbet-i müretteb, daha sonraki dönemlerde fasıl formunun ilk örnekleri

15 İran'da çok zorlu ve büyük bir kumandan olarak bahsi geçen savașçı.

16 Sâsâni hükümdarı Hüsrev'e verilen padișahlar padișahı anlamına gelen kisrâ unvanından türetilmiş isimle padișah kemeri anlamına gelen yapı. 
kabul edilmektedir. Batı Arap dünyasında da nevbe kelimesi fasil anlamında kullanilır (Tura, 1985: 60).

Osmanlı'da fasıl müziğinin meydana geliși, İran-Türk bölgesinde nevbet diye bilinen konser süitinin Arap-Fars biçimi șeklinde etkin olduğu 15. yüzyıla kadar uzanır. Evliya Çelebi, fasıl müziğini nevbete eklenen kısımlardan meydana gelmiș bir süit olarak ifade eder. Ayrıca ritim aleti çalan icracıların fasıllara düzen verdiklerini söyler ve icra șekillerini de fasıl yapmak olarak dile getirir (PopescuJudetz, 2014: 1145-1146).

18. yüzyılın önemli tarihçi ve müzik insanlarından biri olan Dimitri Kantemir, yazmış olduğu “Kitābu 'ilmi'l-mūsīkī 'alā vechi'l-hurūfāt" adlı eserinin nazariyat bölümünde fasıl musikisinin hânende ve sâzende olmak üzere iki șekilde icra edildiğini söyler. Hânendelerin icra ettiği fasılın taksim, beste, nakıș, kâr ve semâi'den meydana geldiğini belirtir. Kantemir, hânende faslındaki formların açıklamalarını tek tek yaptıktan sonra sâzende faslına değinir. Sâzende faslı sırasıyla taksim, peșrev ve semâi'den olușur. Eserde daha sonra hânende ve sâzendelerin sahne düzeninden bașlayarak birlikte icra ettikleri fasıl anlatılır. Kantemir, birlikte icra edilen fasıl için șu ifadeleri kullanır:

“ilk olarak bir sâzende taksime başlar. Taksimden sonra sazlar bir veya iki peșrev çalıp susarlar. Onun üzerine, bir hânende taksime koyulur. Taksimden sonra bir beste, bir nakıș, bir kâr ve bir semâi okunur. Hânendeler susunca, sâzendeler saz semâisine bașlarlar ve saz semâisini tamamlayınca sazların sadece âhenk telleriyle dem tutarlar. Onun üzerine, hânende son olarak bir taksim daha yapar ve fasıl böylece tamam olur" (Tura, 2001: 172, 187).

\section{Sonuç}

Yapılan bu araștırma sonucunda, nevbet-i müretteb türünün çeșitli coğrafyalardaki yansımaları ve tespit edilen türlerle benzerlik ya da farklılıkları diyalektik bir bakıș açısıyla değerlendirilmiștir. Elde edilen bulgularda nevbet-i mürettebin atası kabul edilebilecek nubanın, etkilediği bölgeler arasında Akdeniz coğrafyasındaki öneminin büyük olduğu söylenebilir. Braudel, “Akdeniz'i ihtirasla sevdim" (Braudel, 1990/2017: 21) derken, eski çağlardan bu yana birbirleriyle etkileșim içerisinde bulunan kültürlerin mekânı olan Akdeniz'e hayranlığını dile getirir. Kültürlerarası ilișkilerin yoğun olarak yașandığı bu ortamda, nevbet-i mürettebin ilk örneği diyebileceğimiz nubanın birçok kültürü bünyesinde barındıran Endülüs'ten ve Kuzey Afrika ülkelerinden çeșitli etkileșimlerle değișmeler göstererek farklı coğrafyalara yayıldığı söylenebilir. Bu aynı zamanda nevbet-i mürettebin bir dönüșüme uğradığı fikrini de desteklemektedir. Nevbet-i mürettebin farklı coğrafyalardaki yansımaları olan benzer yapilar, kültürleșme sonucu olușmuștur. Nevbet geleneğinin dünya üzerinde geniș bir coğrafyaya yayılması, toplumlar arası ilișkiler sonucu meydana gelmiștir. Bu kültürlerarası etkileșimin sebepleri, savașlar sonucunda gelișen ticari ve sosyal ilișkiler, coğrafî keșifler, seyyahların yaptıkları geziler olabilir. Bu ilișki ağının yarattığı kültür, yüzyıllar boyunca farklı uygarlıklar merkezinde günümüze kadar aktarılmıștır. Mehdi Kulu Hidâyet'in nevbet-i müretteb ile destgâh arasında kurduğu ilișkiyi müzikte metinlerarasılık kavramı üzerinden okumak 
mümkündür. Mikhail Bakhtin'in ilk olarak edebiyat araștırmaları için kullandığı bu kavrama yeni bir anlam katan André Malraux, sanatçının eserini kendi görüşüyle değil daha önceki eserlerden etkilenerek olușturduğunu iddia eder (PopescuJudetz, 2007: 73). Yeni metinlerin daha önceki metne eklenmesiyle olușan bu edebî hareket, daha sonraları bütün sanat dallarına yayılır. Popescu-Judetz (2007), metinlerarasılık kavramını yazılı müzik kaynakları açısından ele alırken Margarita Celma-Tafalla, müzikte metinlerarasılık kavramını etnomüzikolog Ingrid Monson'ın müziklerarasılık (intermusicality) terimiyle tanımladığını ifade eder. Böylelikle mevcut olan bir müziğe yeni anlam vermek için müziğin yeniden yapılandırılmasını bir neolojizm ${ }^{17}$, olarak kabul eder (Tafalla, 2007).

Angelika Jung, "Quellen der traditionellen kunstmusik der Usbeken und Tadshiken Mittelasiens" [Orta Asya Özbek ve Taciklerinin geleneksel sanat müziğinin kaynakları] adlı kitabında nevbet-i mürettebin diğer kültürlerdeki benzer türlerle ilișkisini bir diyagramda belirtir (bkz. Șekil 1).

17 Bir dildeki sözcüklere benzetilerek yeniden türetilmiș sözcük.

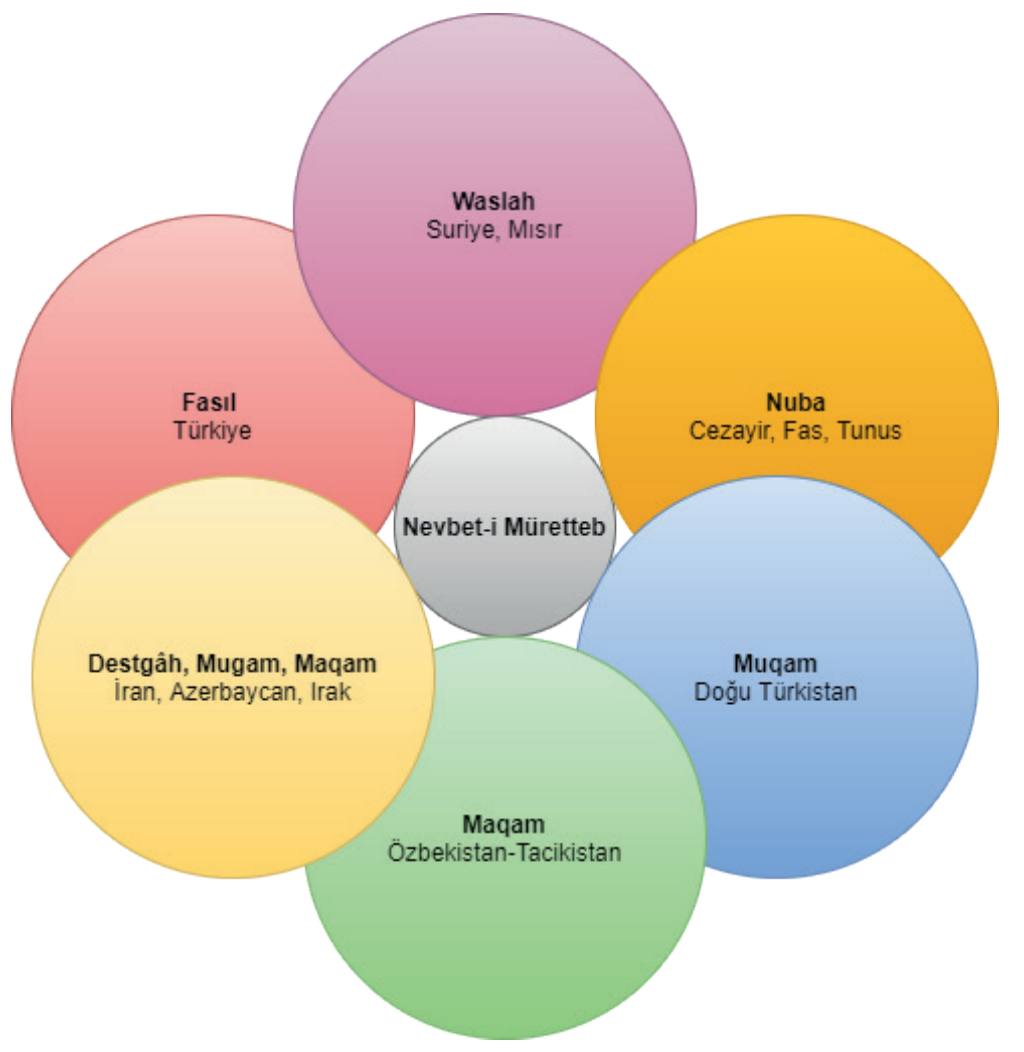

Şekil 1. Nevbet-i müretteb ve diğer coğrafyalardaki dönüșümleri (Jung, 1989: 238).

Șekil 1'de verilen diyagramda nevbet-i mürettebin, Türkiye'de fasıl; Suriye ve Misır'da waslah; Cezayir, Fas ve Tunus'ta nuba; İran'da destgâh; Azerbaycan'da mugam; Irak'ta maqam, Özbekistan ve Tacikistan'da maqam (șaşmakom); son olarak Doğu Türkistan'da muqam türleriyle ilişkileri gösterilir. 


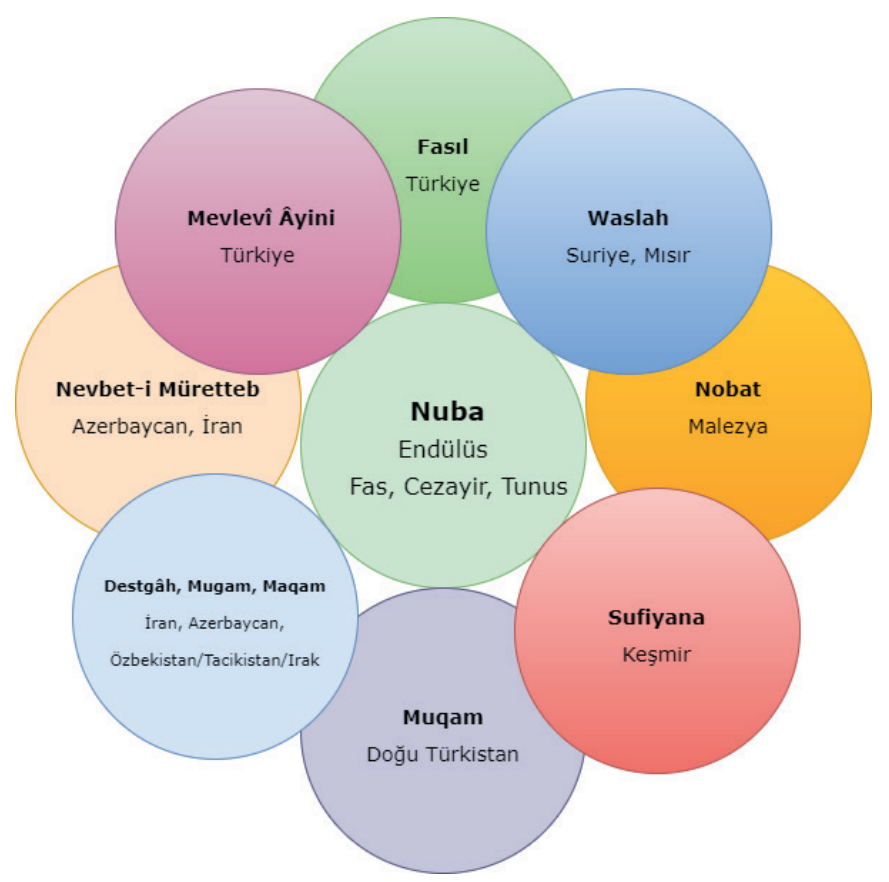

Şekil 2. Nuba kökenli türlerin farklı coğrafyalardaki dönüșümleri

Pacholczyk (1993), Yakın Doğu ve Orta Asya'daki çeșitli İslâmi süit geleneklerini incelerken, Fas ve Keșmir'in müzikleri arasında önemli derecede benzerlik olduğunu fark eder. Daha sonra Endülüs ve Fas'ta nevbe [nuba], Türkiye'de mevlevi ayini ve fasıl, İran'da destgâh, Keșmir'de sufiyana müziğini süit geleneklerine örnek olarak gösterir. Pacholczyk, bahsi geçen müzik türlerinin birbirlerine olan benzerliklerinin farklı coğrafyalar arasındaki siyasi-kültürel ilișkilerin sonucunda gerçekleșmiș olabileceğini ifade eder (Pacholczyk, 1993: 358).

Araștırmamızın sonucunda, Pacholczyk ve Jung'un ortaya koyduğu türler arasındaki ilișkilere Malezya'da icra edilen "nobat" türünün de eklenmesiyle yeni bir diyagram olușturulmuștur (bkz. Şekil 2).

Şekil 2'deki diyagramda, ortaya çıkış tarihi en eski olan nubanın kültürlerarası etkileșimler sonucu geniș bir coğrafyaya yayıldığı görülmektedir. Bu coğrafyaların dağılımı așağıda verilen harita üzerinde temsili olarak gösterilmiștir (bkz. Şekil 3).

Nevbet-i mürettebin farklı coğrafyalardaki izleri üzerine yapılan bu incelemede; günümüzde kendi coğrafyalarında hâlen icra edilen fasıl, nuba, destgâh, șașmakom ve nobat örneklerinde analojik bir ilișki kurulabilmesi mümkündür. 


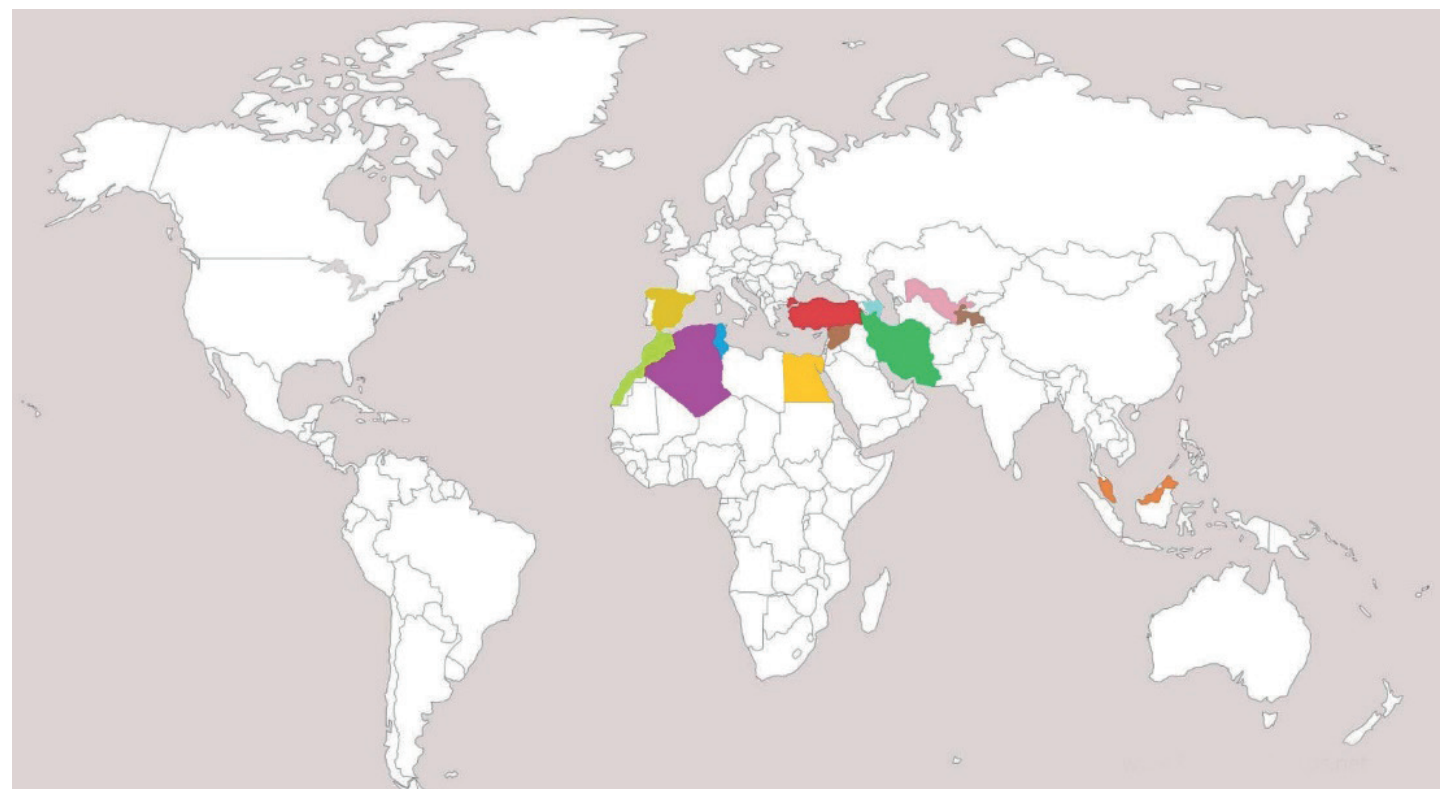

Şekil 3. Çeșitli coğrafyalarda nuba kökenli müzik türleri 


\section{Yazarların Biyografileri}

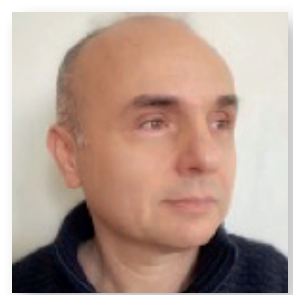

\section{Ali İhsan Alemli}

1971 yılında Gaziantep'te doğdu. İstanbul Teknik Üniversitesi TMDK Temel Bilimler bölümünden 1994 yılında mezun oldu. 2001 yılında İstanbul Teknik Üniversitesi Sosyal Bilimler Enstitüsü’nde yüksek lisans eğitimini tamamladı. 2018 yılında bașladığı Müzikoloji ve Müzik Teorisi doktora programında tez yazım așamasındadır. Halen Kastamonu Üniversitesi Eğitim Fakültesi Temel Eğitim bölümünde öğretim görevlisi olarak çalıșmaktadır.

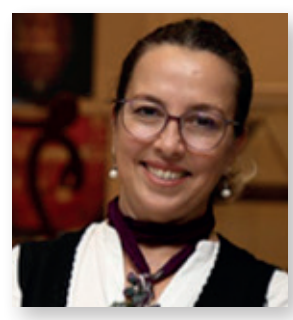

\section{Nilgün Doğrusöz}

1967 yılında İzmir'de doğdu. 1989 yılında Ege Üniversitesi Devlet Türk Musikisi Konservatuarı'ndan mezun oldu. Lisansüstü eğitimini tamamladığı İstanbul Teknik Üniversitesi tarafından 2000 yılında araștırma için yurt dıșına gönderildi. New England Konservatuarı'nda ve Harvard Üniversitesi'nde The Center for Middle Eastern Studies bölümünde misafir öğretim elemanı olarak bulundu. 2004 yılında müzikoloji doçenti oldu. 2013 yılında profesör kadrosuna atandı. 2014'te iTÜ Osmanlı/Türk Müziği Araștırmaları Grubu’nu (OTMAG) kurdu ve çeșitli müzik arșivleri üzerine projeler yürüttü. Halen ITÜ TMDK Müzik Teorisi Anabilim Dalı'nda öğretim üyesidir. 


\section{Kaynakça}

Abbasoğlu, Z. Y. (2015). 15. yüzyıl Herat mûsikî ekolü ve Benâî'nin Risâle-i Mûsikî'si [Yayımlanmamış doktora tezi]. Marmara Üniversitesi.

Abubakr, Z. (2017). Shashmaqom. D. Rahimov (Ed.), In Intangible cultural heritage in Tajikistan (s. 68). Dushanbe publisher house R-Graph.

Agayeva, S. (1979, Eylül). Seyid Nesîmî'nin șiirlerinde musiki motifleri. Mûsiki Mecmuası. 359, 5-6.

Agayeva, S. (2007). Nevbet-i müretteb. Türkiye Diyanet Vakf I İslam ansiklopedisi, 33, 41-43.

And, M. (2003). Music, song and the performing arts. Tradition: Past and present developments. E. İhsanoğlu (Ed.), In The different aspects of islamic culture (p. 704). UNESCO Publishing.

Ardalan, A. (2012). Persian Music Meets West [Bachelor thesis]. Lahti University of Applied Sciences.

Arısoy, M. (1988). Seydî'nin El-Matla' adlı eseri üzerine bir çalıșma [Yayımlanmamıș yüksek lisans tezi]. Marmara Üniversitesi.

Asker, R. \& Asker, L. (2008). Kâșgarl Mahmut ve 11. yüzyıl musikisi üzerine. Türk Dünyası İncelemeleri Dergisi, 8 (1), 31-34.

Behar, C. (2015). Osmanlı/Türk musıkisinin kısa tarihi. Yapı Kredi Yayınları.

Braudel, F. (2017). II. Felipe döneminde Akdeniz ve Akdeniz dünyası (M. A. Kılıçbay, Çev.). Doğu Batı Yayınları. (1990'da yayımlanan orijinal eser).

Cunio, K. E. (2008). Intercultural composition and the realisation of ancient and medieval music. University of Western Sydney.

Çak, Ş. (2018). Geleneksel İran müziğinde kullanılan formlar, çalgılar ve kültürel etkileșim. Ahenk Müzikoloji Dergisi, 3, 44-65.

Çakır, A. (1999). Alişah b. Hacı Büke' nin Mukaddimetü'l Usul adlı eseri [Yayımlanmamıș doktora tezi]. Marmara Üniversitesi.

Çakır, A. (2010). Necmeddîn Kevkebî'nin müzik teorisi. Etüt Yayınları.

Çelik, B. B. (2001). Hızır bin Abdullah'ın Kitabü'l Edvar'ında makamlar [Yayımlanmamıș doktora tezi]. Marmara Üniversitesi.

Davis, R. (2004). Ma'luf: Reflections on the Arab Andalusian music of Tunisia. Lanham. MD: Scarecrow Press.

Doğrusöz, N. (2012). Yusuf Kırșehrî'nin müzik teorisi. Kırșehir Valiliği Yayınları.

Eken Küçükaksoy, F. M. (2009). Türk fasıl müziği geleneği, Fasıl Serisi I/ Kürdilihicazkâr Faslı. 1, 3-11. ITÜ TMDK Yayınları.

Erkoçoğlu, F. \& Arslan, F. (2013). Ziryâb. Türkiye Diyanet Vakfı İslam ansiklopedisi, 44, 464-465.

Farhat, H. (2004). The Dastgah concept in Persian music. Cambridge University Press. 
Farmer, H. G. (1945). The minstrelsy of the Arabian nights. Hinrichsen Edition.

al-Faruqi, L. I. (1985). The suite in Islamic history and culture. The World of Music, 27 (3), 46-66.

Hodeir, A. (1992). Müzik türleri ve biçimleri (i. Usmanbaş, Çev.). İletişim Yayınları. (1990'da yayımlanan orijinal eser).

İnayet, A. (2007). Uygur on iki makamı ve edebiyatı, Turkish Studies/Türkoloji Araștırmaları Dergisi, 2 (2), (365382). http://dx.doi.org/10.7827/ TurkishStudies.77

Jung, A. (1989). Quellen der traditionellen kunstmusik der Usbeken und Tadschiken mittelasiens (Beiträge zur Ethnomusikologie 23), Hamburg: Verlag der Musikalienhandlung Karl Dieter Wagner.

Kahraman, S.A. \& Dağlı, Y. (1999). Evliyâ Çelebi seyahatnâmesi Evliyâ Çelebi b. Derviş Mehemmed Zıllî III. Kitap. Yapı Kredi Yayınları.

Kahraman, S.A., Dağlı, Y. \& Dankoff, R. (2003). Evliyâ Çelebi seyahatnâmesi Evliyâ Çelebi b. Derviș Mehemmed Zıllî VIII. Kitap. Yapı Kredi Yayınları.

Keykâvus bin İskender. (t.y.). Kābusnâme, (i. Mercimek Ahmed, Çev., A. Özkırımlı, Haz.). Tercüman Yayınları.

Kolukırık, K. (2009). Abdülkâdir Merâgî ve Şerhu'l-Edvâr adlı eserinin XIV. yüzyıl Türk mûsikîsi nazariyatındaki yeri [Doktora Tezi]. Ankara Üniversitesi.

Lucas, A. E. (2019). Music of a thousand years a new history of Persian musical traditions. Oakland: University of California Press. https://doi. org/10.1525/luminos.78

Marks, E. (t.y.). Andalusian nuba. https: / / www.jewish-music.huji.ac.il/ content/andalusian-nuba

Mason, J. (1996). Qualitative researching. Sage.

Neubauer, E. (1995). Safi al-Din alUrmawi. In C.E. Bosworth, E. Van Donzel, W.P. Heinrichs and G. Lecomte (Eds.), The encyclopaedia of Islam, 8, 806.

Özaydın, A. (2007). Nevbet. Türkiye Diyanet Vakfı İslam ansiklopedisi, 33, 38-41.

Pacholczyk, J. (1993). Early Arab suite in Spain: An investigation of the past through the contemporary living traditions. Revista de Musicología 16 (1), 358-66.

Parmaksız, M. N. (2016). Bodleian kütüphanesi 127-128 numaralı Türk musikisi güfte mecmuasının incelenmesi [Yayımlanmamıș doktora Tezi]. Gazi Üniversitesi.

Popescu-Judetz, E. (2007). Türk musıki kültürünün anlamları (B. Aksoy, Çev.). Pan Yayıncılık.

Popescu-Judetz, E. (2014). Osmanlıda fasıl. H. C. Güzel (Ed.), Yeni Türkiye Türk musikisi özel sayısı içinde (s.1144-1150). Yeni Türkiye Stratejik Araștırma Merkezi.

Racy, A. J. (1983). The waslah: A compound-form principle in Egyptian 
music. Arab Studies Quarterly 5(4), 396403.

Raja Iskandar bin Raja Halid. (2015). The malay nobat: A history of encounters, accommodation and development [Doktora tezi]. King's College.

Sachs, C. (1943). The rise of music in the ancient world. W.W. Norton and Co. Inc.

Seljuq, A. (1976). Some notes on the origin and development of naubat. Journal of the Malaysian Branch of the Royal Asiatic Society, 49 (1), 141-142.

Sezikli, U. (2007). Abdülkâdir Merâgî ve Câmiu'l-Elhân'ı [Yayımlanmamıș doktora tezi]. Marmara Üniversitesi.

Shiloah, A. (1995). Music in the world of Islam: Socio-cultural study. MI: Wayne State University Press.

Sumits, W. \& Levin, T. (2012). Maqom traditions of the Tajiks and Uzbeks. T. Levin and E. Köchumkülova (Eds.), In Music of Central Asia: An introduction (pp. 234-250). Indiana University Press.

Şahin, E. (2011). Bâkî Divanı'na göre 16. yüzyıl Osmanlı toplum hayatı [Yayımlanmamıs doktora tezi]. İstanbul Üniversitesi.

Tafalla, M. C. (2007, 25 Ocak). Intermusicalité. http://sens-public. org/articles/377/

Tura, Y. (1985). Türk musikisi formları eski formlar, Kaynaklar, 4, 59-62.

Tura, Y. (2001). Kantemiroğlu kitabu ilmi'l-musiki alâ vechi'l-hurûfât, musikiyi harflerle tespit ve icra ilminin kitabı I. cilt. Yapı Kredi Yayınları.

Turan, O. (2008). Selçuklular tarihi ve Türk-İslâm medeniyeti. Ötüken Neșriyat.

Uslu, M. \& Kurtuldu, Ö. R. (2018). Kültürlerarası iletișimde müziğin yeri ve toplumsal yansıması, "Türk- Macar kültürü üzerine bir değerlendirme”. 25. İstanbul Türk müziği festivali "Çölleșen ruhumuzu müzikle yeșertelim" Müzikte Stratejik Yaklașımlar Uluslararası Sempozyumu Bildiriler Kitabı. Eğitim, Kurumlar, Kültür Politikaları, Yayıncılık, Terminoloji. 209-219.

Uslu, R. (2017). Nevbet-i müretteb: XI-XV. yüzyılların gözde musiki biçimi nasıldı? Müzikolojik değerlendirme. Türk Dünyası Sosyal Araștırmalar Dergisi. 15, 176-204. https://doi.org/10.16989/ TIDSAD. 1340

Wright, O. (1992). Words without songs. Routledge.

Wright, O. (1993). Nawba. C.E. Bosworth et al. (Eds), In Encyclopedia of Islam, vol. 7: 681-8. Leiden: Brill. 


\section{An investigation on the traces of Nevbet-i Müretteb in different geographies}

\section{Extended Abstract}

Various changes have occurred in Turkish music culture since prehistory. In this process, music culture has taken its present form by constantly transforming. In the 10th century, Farabî did not accept the thoughts of Pythagoras about the sounds of the planets that he had put forward hundreds of years ago, and he developed the 17-tone sound system on the Khorasan Drum by explaining the occurrence of the sound by striking the objects against each other. Farabî, with his work al-Mûsîna'l-kebîr, guided many music people who came after him in the history of maqam music.

Farabi's 17-sound system in maqam music showed its effect for many years with the contributions of Urmevî and appeared in the edvars of theorists such as Abdülkadir Merâgi, Yusuf Kırșehrî, Hızır bin Abdullah, Ahmedoğlu Șükrullah. In these edvars, perde (pitchs), makam (maqams) and usûl (rhytmic cycles) are shown with circles, and information about musical genres is given along with the âvâze, șûbe and terkip. Various genres and forms have emerged within the framework of maqam music in different centuries and geographies. One of them is nevbet-i müretteb, which has influenced music circles for centuries. Nevbet-i müretteb, which is a long-term music genre consisting of four or five parts in the same makam, has been compared to a suite by some musicologists. There is extensive information about nevbet-i müretteb, especially in the works of Abdülkadir Merâgi. In addition, Yusuf Kırșehrî, Hızır bin Abdullah and Seydî gave various information about nevbet-i müretteb in their works.

Despite the great interest of nevbet-i müretteb in music circles for a long time, the fact that its name was not mentioned as of the 16th century and there were very few studies on the subject necessitated this research.

In this study, using the descriptive approach in the scanning model of the qualitative research method, the transformation of the nevbet-i müretteb in different cultures was evaluated in terms of the concepts of interculturality and intertextuality. In these evaluations, an interdisciplinary approach was taken within the fields of history, musicology, literature and sociology.

As a result of this research, it has been determined that nevbet-i müretteb has undergone a transformation as a result of intercultural interactions by establishing intertextual relations. This transformation spreads over a wide geography and appears with different names in different cultures. Species found to be similar to nevbet-i müretteb: Nuba in Andalusia and Maghreb countries, fasıl in Turkey, waslah in Syria and Egypt, dastgah in Iran, mugam in Azerbaijan, maqam in Iraq, Uzbekistan and Tajikistan it manifests itself as maqam (shashmaqam) in, nobat in Malaysia, and muqam in East Turkestan. It is possible to point out the nuba, which we encountered in the 8th and 9th centuries in written sources, as the oldest of the mentioned species, for the starting point of nevbet-i müretteb.

It can be thought that this research, which examines the effects of nevbet-i müretteb on its traces in different geographies, will constitute a resource for researchers who will study on the subject with a limited literature. In the studies to be carried out after this study, it may be possible to reach a reconstructed nevbet-i müretteb with the comparative analyzes of the cyclical works still performed in various cultures.

\section{Keywords}

interculturality, intertextuality, nevbet-i müretteb, nuba 